\title{
Reforming the Rules of the Parliamentary Game: Measuring and Explaining Changes in Parliamentary Rules in Austria, Germany, and Switzerland, 19452010
}

\author{
ULRICH SIEBERER, WOLFGANG C. MÜLLER and \\ MAIKO ISABELLE HELLER
}

Questions of institutional change have recently received increased attention in comparative politics. Even though comparative legislative research has identified important effects of parliamentary rules on processes and outputs as well as large variation across countries, we know very little about changes in these rules. This article takes several steps towards mapping and explaining rule changes in European parliaments. Theoretically, it sketches a model explaining such changes based on the rational choice notion of institutions as endogenous equilibria. Methodologically, it proposes two complementary approaches to measure rule changes. In combination, these measures allow us to identify the content, relevance, and effects of changes in parliamentary rules. Empirically, the article provides the first systematic analysis of all changes in the parliamentary standing orders of Austria, Germany, and Switzerland since 1945. This analysis demonstrates that parliamentary rules are changed frequently and massively. It also identifies differences across countries and content areas that are largely in line with theoretical expectations.

The last two decades have witnessed an increased scholarly interest in questions of institutional design. On the theoretical level, both rational choice theorists and historical institutionalists have struggled with questions of institutional choice, stability, and change (see e.g. Calvert 1995; Greif and Laitin 2004; Héritier 2007; Knight 1992; North 1990; Shepsle 2006a; Tsebelis 1990 for rational choice studies and Mahoney 2000; Mahoney and Thelen 2010a; Pierson 2004; Streek and Thelen 2005; Thelen 2003 for

Correspondence Address: ulrich.sieberer@uni konstanz.de 
historical institutionalist accounts). Empirical studies have analysed stability and change in various central institutions of modern democracies such as the regime type (e.g. Elster et al. 1998; Sartori 1997), constitutions (Elkins et al. 2010), electoral systems (e.g. Benoit 2004, 2007; Katz 2005), the power of the cabinet (Cox 1987), second chambers of parliament (e.g. Congleton 2003; Russell 2000), and the territorial division of power (e.g. Benz and Behnke 2009; Swendon and Jans 2006). By contrast, we know far less about the stability and change of parliamentary rules. This neglect is surprising because parliamentary rules can determine winners and losers of the political game and are often highly contested among parliamentary actors. Furthermore, various studies have emphasised institutional variation across countries (e.g. Döring 1995a; Strøm et al. 2003) and have stressed the relevance of these rules for parliamentary behaviour and outcomes (e.g. Cox 2000; Döring and Hallerberg 2004; Tsebelis 2002).

In this article, we take several steps towards filling this gap by focusing on three questions: (1) Why are parliamentary rules changed? (2) How can we measure such changes? (3) How much have parliamentary rules changed in Austria, Germany, and Switzerland since 1945 and how can we account for observed patterns of stability and change? We argue theoretically that parliamentary rules can be understood as endogenous equilibria in an underlying game in which parliamentary actors constantly decide whether to conduct business in line with existing rules or to change them. Institutional change comes about when this equilibrium is disturbed due to changes in the actor constellation or the external environment of parliament leading a sufficiently large majority of actors to expect higher payoffs with regard to their substantive goals from a specific alternative to the institutional status quo. Methodologically, we suggest two complementary approaches to measure these changes - one well established in the literature, the other one newly developed in this article. Together, these approaches allow us to capture institutional change both in its full breadth and in considerable analytical depth. Empirically, we demonstrate the usefulness of our new approach for tracing macro patterns of change in parliamentary rules in Austria, Germany, and Switzerland over the entire post-World War II period. Our analysis shows that parliamentary rules are changed frequently and massively and describes observed macro patterns with regard to the extent and content of these changes. Furthermore, it provides initial evidence that the observed patterns are in line with one key aspect of our theoretical model, i.e. the impact of longterm changes in the parliaments' external environment.

We proceed as follows: the next section reviews the state of research on changes in parliamentary rules. In the third section, we sketch our theoretical model for explaining parliamentary rule change. The fourth section discusses our measurement approach. The fifth section analyses rule changes in Austria, Germany, and Switzerland since 1945 empirically. We conclude by summarising our main findings and pointing out directions for future research. 


\section{Parliamentary Rules and Institutional Change}

Conceptually, we define parliamentary rules as the set of formal rules that govern the conduct of politics in the parliamentary arena, including parliament's relation with other bodies. ${ }^{1}$ These rules are typically codified in at least two legal documents: Constitutions regulate parliamentary business in general terms whereas more detailed rules are contained in special documents labelled 'standing orders', 'rules of procedure', or the like. ${ }^{2}$ The latter's legal status varies across countries, ranging from quasi-constitutional rank via ordinary legislation to assembly-adopted internal rules. Accordingly, some enjoy similar entrenchment as constitutions whereas others remain within the discretion of any parliamentary majority (Bergman et al. 2003: Table 4.3; Müller 2002: 280-81). Empirically, this article focuses mostly on the second type of documents that contain the large majority of parliamentary rules and are changed much more frequently than parliamentary rules entrenched in the constitution.

Changes in parliamentary rules have rarely been addressed in the comparative politics literature. While a sizeable body of literature describes cross-sectional variation in parliamentary institutions (e.g. Döring 1995a; Strøm et al. 2003), few studies explicitly deal with the choice of specific rules and their dynamics. Only one truly comparative study tries to explain differences in three particular rules (rights of individual MPs to initiate bills and to offer amendment and the requirements for invoking cloture) across 55 legislative bodies in 32 countries (Taylor 2006). However, the study is purely cross-sectional in design with only one observation per parliament and does not analyse rule changes as such. With regard to the distribution of leadership offices in cabinet and parliament (so-called 'mega-seats'), Carroll et al. (2006) argue theoretically that existing rules should favour the interests of some parliamentary actors, especially the parliamentary majority. Their empirical analysis, however, focuses on the theorised effect of these rules the distribution of mega-seats - not the rules themselves. Rule changes as such have been studied intensively only with regard to the US Congress (Binder 1996, 1997, 2006; Schickler 2000, 2001; Wawro and Schickler 2006; Dion 1997; Polsby 2004). The main theoretical question in this literature is whether institutional change should be explained from a partisan perspective or with a non-partisan model focusing on the median deputy (compare Binder 1996, 2006 and Schickler 2000). In contrast to such theorydriven approaches, institutional change in European parliament has been analysed in mostly descriptive single-country studies focusing on one or a few major reforms (Thaysen 1972; Marschall 1999 for Germany; AuracherJäger 1997 for Austria; Norton 2000, Flinders 2007 for the UK; Foundethakis 2003 for Greece; Filipe 2009 for Portugal).

Thus we lack both systematic descriptive accounts of the stability and change of rules in European parliaments over time and a theoretical and empirical understanding of the factors causing such changes. This limited 
knowledge contrasts sharply with the relevance of the topic. Parliament is the central political institution in modern democracies in the sense that major political decisions require parliamentary approval or at least its tacit toleration. Decision-making in European parliaments is mainly structured by two factors: Political parties as the main actors pursuing their respective goals; and parliamentary rules structuring their interaction and influencing the outcome of parliamentary struggles. While parties have long been at the centre of attention in comparative politics, systematic research on parliamentary rules is of more recent vintage. Theoretically, the rational choice institutionalist literature shows that parliamentary rules affect actors' choices by constraining the alternatives to choose from and by assigning payoffs to different courses of action. Thus, rational actor behaviour in parliament is guided by preferences but constrained by institutions, and many outcomes of parliamentary processes constitute structure-induced equilibria that critically depend on the rules in force.

Empirically, comparative legislative research has identified a large variety of rules that have systematic effects on parliamentary behaviour and outcomes. In the context of law-making, such rules include the right to initiate legislation (Mattson 1995), the order of voting and the majority necessary to win a vote (Rasch 1995), the voting mechanism used (Saalfeld 1995), unilateral amendment powers of cabinet actors (Heller 2001), and the linkage of legislative proposals to questions of confidence (Huber 1996). However, the relevance of parliaments in parliamentary democracies is not restricted to law-making. Parliaments also bring about and hold accountable the cabinet, elect officeholders outside cabinet, and provide an important arena for parties to address each other and the public in the context of political competition (Sieberer 2011). Thus, we should also analyse parliamentary rules beyond the narrow law-making process. Such rules include instruments to control the cabinet (Schnapp and Harfst 2005) and reduce informational asymmetries via parliamentary questions (Wiberg 1995; Russo and Wiberg 2010) and committees of inquiry; electoral powers with respect to various external bodies such as heads of state, constitutional courts, audit institutions, and ombudsmen (Sieberer 2010, 2011); rules on agenda setting in the plenary (Döring 1995b); rules on the format of debates and their compatibility with demands by the mass media (Franklin 1989; Marschall 2001); and last but not least, rules on the allocation of internal offices (Carroll et al. 2006; Jenny and Müller 1995) and material resources such as staff, rooms, and money among parliamentary party groups.

As parliamentary rules systematically affect outcomes, it is hardly surprising that political actors care a great deal about them and think about how to use rules to advance their substantive goals. This is most obvious in situations where the meaning of a rule is contested and actors compete about its interpretation. Similarly, processes of parliamentary reform often take years to complete involving hearings of many experts and engaged debates among MPs. However, we know very little about how 
frequently, for what reasons, and with what results rules are changed in parliamentary democracies. In addressing these questions, it is useful to distinguish between two broad types of changes based on their effect on political competition (Tsebelis 1990). 'Redistributive changes' favour some actors, usually the current majority, at the expense of others whereas 'efficient changes' enhance the utility of all or almost all actors. ${ }^{3}$ Most likely, different processes bring about these different types of changes. We take this point up in the next section, where we sketch a theoretical framework for explaining changes in parliamentary rules.

\section{Explaining Changes in Parliamentary Rules}

Recent political science work on institutional change relies on two broad theoretical frameworks: Rational choice institutionalism (e.g. Shepsle 1986, 2006b; Tsebelis 1990; Weingast 2002) and historical institutionalism (e.g. Pierson 2004; Pierson and Skocpol 2002; Thelen 2003; Mahoney and Thelen 2010b). In very general terms, the former focuses on institutional design as a rational decision by political actors trying to achieve their goals by installing rules leading to favourable outcomes, whereas the latter concentrates on the question of how historical continuities guide and constrain institutional development. This article is rooted in the rational choice paradigm. From this perspective, institutions are rules that systematically influence outcomes by affecting the moves actors can make and the payoffs they receive from their choices (e.g. North 1990; Tsebelis 1990). Most rational choice institutionalist work treats rules as exogenous and focuses on their effects on actor behaviour and outcomes. However, institutions are not God-given features of a political system but are themselves created, maintained, and changed by human agency.

Following this insight, the design and change of institutions has received increased theoretical and empirical attention in recent years (e.g. Calvert 1995; Greif and Laitin 2004; Shepsle 2006a, and as an early example Cox 1987). On the theoretical level, models of endogenous institutions start from substantive goals that actors pursue. For political actors in parliamentary democracies, i.e. for the most part political parties, the goals of winning votes, influencing policy, and attaining office are central (Müller and Strøm 1999; Strøm 1990). Various institutional rules affect the ability of actors to reach these goals: Electoral fortunes are influenced by electoral system rules. Once the seats are allocated, the ability of actors to influence policy depends on rules of parliamentary decision-making and on the existence of alternative institutional channels of influence (e.g. powerful heads of states, second chambers of parliament, sub-national units, constitutional courts, and instruments of direct democracy). Finally, the chances of obtaining valuable offices hinge on rules for winning such positions (e.g. cabinet investiture rules and selection rules for internal and external offices). As institutions systematically affect actors' ability to reach their substantive 
goals, institutional design constitutes a distinct strategy to further these goals and actors can be assumed to have institutional preferences derived from their substantive goals.

Given such preferences, institutions can be understood as an equilibrium emerging from an underlying game in which actors constantly decide whether to abide by or change established ways of doing business. Thus, rules are neither exogenous nor ontologically different from behaviour (Diermeier and Krehbiel 2003; Shepsle 2006a). Instead, they are persistent behavioural patterns emerging from the repeated interaction of rational, goal-oriented actors (Calvert 1995). Such patterns of doing business, which are often codified in formal rules, can display high stability as long as the underlying distribution of institutional preferences is not disturbed. This 'institutions-as-equilibrium' perspective is theoretically more powerful than earlier views of institutions as exogenous rules of the game (e.g. North 1990) because it allows us to explain decisions within institutions and decisions about institutions using the same model of strategic interaction among rational actors.

Based on this perspective, institutional change should occur when the equilibrium in the underlying game about institutions is disturbed. Such disturbances can originate from two sources that can be tied to the distinction between redistributive and efficient change introduced above. First, changes in the actor constellation and thus the competitive context can lead actors to expect higher payoffs from rules that are different from the existing ones. Such changes include new cabinet compositions and particularly new cabinet formats (e.g. coalition rather than single-party or minority rather than majority cabinets), large shifts in voter support leading governing parties to fear defeat in future elections, and changes in the ideological makeup of parliament and cabinet after which a new majority aims for major departures from the policy status quo that may be easier to achieve under different rules. Institutional reforms based on changes in the actor constellation are likely to be of the redistributive type, i.e. advance the interests of some actors, usually the current majority, ${ }^{4}$ at the expense of others, usually opposition parties.

Second, equilibrium institutions can come under pressure due to developments in their external environment - in the sense of both exogenous shocks and long-term trends - that call for the adaptation of rules. Such external developments include shocks like regime changes after wars and revolutions as well as long-term trends such as increased parliamentary workload and complexity of policy questions, developments in the international realm like European integration, changes in the media system, and technological change more generally. External developments often pose challenges for all parliamentary actors alike and are thus likely to result in efficient changes supported by all or almost all actors. However, reforms in reaction to external developments can also have redistributive consequences in how they distribute reform benefits and can be used by rational actors in 
ways that increase their own position in future political competition. This point is nicely illustrated in Cox's (1987) argument on how a massive increase in the number of bills induced by altered objective demands from urbanised constituencies (an external development) led rational actors to increase centralisation of decision-making power in the cabinet (a massive change in parliamentary rules). This change not only solved the common pool problem regarding scarce parliamentary time but at the same time strengthened the position and thus served the personal interests of (majority) party leaders.

Disturbances of equilibrium institutions are necessary but not sufficient conditions for institutional change. They are not sufficient because actors face constraints and costs when altering rules which may outweigh the benefits of reforms. Constraints derive mainly from exogenous institutions ('second-order institutions' in the terminology of Diermeier and Krehbiel 2003). First, exogenous institutions govern and sometimes hinder the process of changing rules. For example, some rules can only be changed with qualified majorities, and others such as basic human rights in the German Grundgesetz or the equal representation of states in the US Senate cannot be altered in a lawful fashion at all. ${ }^{5}$ Second, exogenous institutions can reduce the effects of changing particular rules. For example, the consequences of changing standing orders are limited when basic parliamentary rules are contained in the constitution. Similarly, the benefits the majority can draw from changing the rules of the parliamentary game are reduced when other veto players such as heads of state and second chambers can negate outcomes of the parliamentary process (Sieberer 2006). Third, exogenous institutions can provide actors with incentives and disincentives to pursue specific rule changes. For example, party-based electoral systems provide incentives for MPs to support a strong position of party groups in parliamentary business whereas more candidate-based electoral rules should increase the demand for opportunities to create individual visibility in parliament.

In addition to the constraining effect of second-order institutions, institutional change entails political and electoral costs. First, reforming rules involves transaction costs and thus binds resources that cannot be spent to serve actors' substantive goals directly. Second, institutional change, especially of the redistributive type, can draw negative public reactions when perceived as partisan tinkering with fundamental rules of fairness. Thus, actors have to weigh benefits from new rules against costs associated with the reform process and public reactions to it. To complicate matters further, costs and benefits are rarely achieved simultaneously, raising the question of temporal discounting. While transaction costs and political costs of institutional change occur before or shortly after a reform, the full benefits of new rules often materialise only in the more distant future. Furthermore, these benefits are uncertain because actors can neither perfectly foresee the effects of institutional change nor know in what position they will find themselves in the future. 
To sum up the theoretical argument, institutional change should be observed when the necessary (according to second-order institutional rules) majority of actors expects a specific alternative to the institutional status quo to yield higher payoffs with regard to their substantive goals. To calculate these payoffs, actors have to (1) weigh potential benefits of new rules against the political and electoral costs of reform, (2) decide on how to discount future compared to current payoffs, and (3) figure in the uncertainty of institutional effect and of their own future position under the new rules. This calculation clearly involves high degrees of uncertainty. This, in turn, explains why actors do not constantly reshape institutions as was originally expected by Riker (1980). ${ }^{6}$ Instead, high costs and uncertain benefits often lead actors to play the game within existing rules, giving these rules a quasiexogenous quality. Thus, institutional stability can be explained along the lines indicated above but should not be taken for granted.

Our theoretical argument will be specified more thoroughly in subsequent work to yield testable hypotheses on the conditions favouring or hindering changes in parliamentary rules as well as specific types of such changes. In this article, we restrict ourselves to spelling out expectations about the effects of changes in the external environment calling for the adaptation of parliamentary rules. We discuss three hypotheses concerning the consequences of European integration, public demand for democratic reforms, and increases in the workload and complexity faced by parliaments in the fifth section and find initial empirical evidence in line with our model.

\section{Measuring Changes in Parliamentary Rules}

Before turning to the empirical analysis, we have to address the question of how to measure institutional change in parliamentary rules. Existing studies often focus on major and highly publicised parliamentary reforms. This approach misses changes that are less far-reaching by themselves and may thus lead to biased assessments of the frequency and extent of rule changes. Ideally, a measure of institutional change should capture all instances of reform and account for their content, relevance, and redistributive or efficient effects. In practice, no single measure can achieve all these goals. Thus, we distinguish two complementary measurement approaches.

First, we can code specific rules that theoretical and empirical work has identified as important for parliamentary processes and outcomes. Such variables include rules on agenda setting (Döring 1995b; Rasch and Tsebelis 2011), voting procedures (Rasch 1995), question rights (Wiberg 1995; Russo and Wiberg 2010), committee powers (Mattson and Strøm 1995, 2004), electoral powers (Sieberer 2010, 2011) and the rights of parliamentary party groups (Heidar and Koole 2000). Changes identified by this approach are very likely to have relevant consequences for parliamentary business. Furthermore, their content and redistributive consequences (if any) can be assessed relatively easily because we have a clear theoretical understanding 
of their effects. On the other hand, this approach covers only a comparatively small share of all parliamentary rules and, more problematically, focuses solely on areas that have received systematic scholarly attention in the past. Thus, it may overlook relevant changes in less thoroughly studied areas of parliamentary activity.

To avoid these problems, our second measurement approach relies on a quantitative analysis of the entire text corpus of parliamentary rules. It compares the complete text of successive versions of parliamentary rules and detects all changes in the text even if they refer to rules that have not been analysed by previous research. ${ }^{7}$ Thus, it is well suited to identify macro patterns of stability and change across all rules. We further code all rules according to their content which allows us a first assessment of the content of changes and the identification of areas displaying high and low stability. On the downside, this approach can neither capture the detailed substance of rule changes nor measure their efficient or redistributive effects.

In the empirical section of the article, we demonstrate the usefulness of our novel measure and provide a quantitative analysis of all versions of parliamentary standing orders that were in force in the lower houses of the Austrian, German, and Swiss parliaments during the post-World War II period. ${ }^{8}$ We hand-coded all subparagraphs ${ }^{9}$ into one content-based category according to a detailed coding scheme containing 77 mutually exclusive categories. All subparagraphs were coded independently by two of the authors. Afterwards, all discrepancies in coding were discussed in detail and assigned to one category based on the consensus of both coders. For the descriptive analysis, we aggregate our 77 categories into the following five broad ones:

- Plenary decision-making contains rules on parliamentary initiatives, plenary agenda setting, plenary debate, plenary voting, ordinary legislative procedures in the plenary, specific decision-making procedures in the plenary (such as constitutional change, procedures on money bills, the ratification of international treaties, the conduct of EU business, elections of external officeholders by the plenary, and non-legislative resolutions) as well as general rules on the relations of parliament to the public.

- Intra-parliamentary units comprises rules related to the organisation, powers, and procedures of parliamentary committees, parliamentary leadership offices (e.g. the President, Vice-Presidents, and coordinating bodies such as a Council of Elders), and parliamentary party groups as well as powers and duties of individual deputies.

- External relations and control includes rules on the relationship between parliament and the cabinet (investiture votes, confidence and noconfidence procedures, and prerogatives of cabinet members in parliamentary business), control powers of parliament (question rights and topical debates), parliamentary relations to external bodies (like 
constitutional courts, the head of state, audit institutions, and ombudsmen) as well as rules on how parliament responds to public demands voiced via direct democratic instruments and petitions.

- Changing rules contains provisions for the process of changing and interpreting parliamentary rules themselves.

- Other is a residual category comprising rules on parliamentary documents, parliamentary administration, the first convening of parliament after an election, discontinuity before elections, final provisions on coming into force of rules, country-specific rules (e.g. dealing with language issues in Switzerland), and miscellaneous rules that cannot be classified in any of the systematic categories.

Based on this classification, we count the number of words in each category. Comparing these numbers over time gives us a measure of the net change from one version of the rules to the next. However, this net change only provides a lower limit of the actual change because additions and deletions referring to rules in the same category will cancel each other out and replacements of one word by another are not picked up as changes. Thus, we use a second indicator measuring gross changes. For this measure, we identify all words that were added, deleted, and replaced compared to the previous version and add the three together.

\section{Empirical Patterns of Change in Austria, Germany, and Switzerland}

\section{Case Selection and Expectations}

Why do we use Austria, Germany, and Switzerland for our empirical analysis? On the one hand, these countries are similar and thus easy to compare. First, they use the same language facilitating the comparison of text length because we do not have to take into account differences in the number of words a language needs to express a given content. Second, they share a common legal tradition making their parliamentary rules easier to compare. On the other hand, the three countries differ with regard to relevant independent variables. These differences can be exploited to formulate expectations about different patterns of rule change. ${ }^{10}$

First, changes in parliamentary rules require a two-thirds majority in Austria whereas simple majorities suffice in Germany and Switzerland. Thus, changes should be less frequent in Austria compared to the other two countries. Assuming that at least redistributive changes should not occur against the will of a government party, such changes should only occur during periods of Grand Coalitions in Austria as only this type of government can typically rely on the required parliamentary majority. As there is no reason to assume efficient changes not to be distributed uniformly over time, changes should in general be more frequent during times of 
Grand Coalition government compared to single-party cabinets and coalitions with a narrow parliamentary lead.

Second, Austria and Germany are parliamentary systems of government, whereas Switzerland has an assembly-independent system in which the executive (Bundesrat) is elected by parliament but not accountable to it after its election. Thus, the Swiss system is closer to a classic separation of powers logic. Accordingly, we expect parliamentary control powers to be more elaborate in Switzerland.

Third, the three parliaments had very different pre-1945 trajectories and differed in many ways at the starting point of our investigation. One such difference is that the Swiss parliament developed smoothly, while the German and Austrian ones went through major upheavals with regime changes. The Austrian parliament probably experienced the single most severe one with the end of the Habsburg Empire in 1918. The rules of procedure in force in 1945 were still largely adapted from those of the monarchy (Auracher-Jäger 1997) and may thus have entailed a great need for change. While post-war Germany initially also relied on parliamentary rules pre-dating the new regime, they were of much more recent origin. ${ }^{11}$ Another difference between the three countries is the level of professionalisation in 1945. Switzerland was a clear laggard in this respect due to its character as a part-time 'militia parliament'. Over the period covered, however, all three parliaments were faced with increasing demands from greater complexity and specialisation of policy issues demanding adaptive changes in parliamentary rules. Thus, we expect overall more frequent and more substantial changes in Switzerland in the attempt to make parliament fit for meeting these new requirements.

In addition to these differences between countries, we expect some differences between the content categories with regard to reform activity. Rules on plenary decision-making refer to parliamentary tasks that have always been relevant. While we might see some changes, especially due to a more detailed regulation of plenary debates, the overall pattern should be relatively stable. We expect the same stability with regard to rules about changing and interpreting parliamentary rules and on miscellaneous rules that do not fall into any of the content categories discussed above. ${ }^{12}$ On the other hand, increased demands for professionalisation and specialisation should be observable in large changes in rules relating to the internal organisation of parliament. Similarly, we expect an expansion of rules on external relations and control that mirror the recurrent discussions about democratic reform and 'strengthening parliament'.

Our empirical analysis focuses on the standing orders of the lower houses of parliament in the three countries. In Austria and Germany, these rules are contained in a single document (the Geschäftsordnung des Nationalrats and the Geschäftsordnung des Deutschen Bundestages, respectively), whereas the Swiss rules are divided up between two different legal documents: The Parlamentsgesetz (until 2002 called Geschäftsverkehrsgesetz) contains rules 
on the legislative process in both chambers of parliament and its relationship to the executive branch, whereas the Geschäftsreglement des Nationalrats mainly comprises specific rules on the internal organisation of the lower chamber. For the analysis, we combine both documents but delete the few passages of the Parlamentsgesetz that refer exclusively to the executive branch or the second chamber. Our analysis starts with the first reform after 1945 (1948 in Austria, 1951 in Germany and 1946 in Switzerland) and covers all reforms until 1 January 2010.

\section{Macro Patterns of Change}

How stable are parliamentary standing orders over time? In the period covered, the Austrian, German, and Swiss rules were changed on 12, 37, and 61 occasions, respectively. As expected, Austria witnessed by far the fewest changes. Furthermore, 8 of the 12 reforms were passed under a Grand Coalition government of the SPÖ and ÖVP for which the qualified majority requirement to change the rules was easy to achieve. ${ }^{13}$ Conversely, the Swiss rules were reformed most frequently, which may be due to the originally low professionalisation of this militia parliament.

As a consequence of the various reforms, the total length of the rules grew massively: Treating the first version in the sample as baseline, the Austrian rules almost tripled in length (2.98 times longer), and the German and Swiss rules grew by factors of 2.59 and 2.69 , respectively. ${ }^{14}$ Thus, parliamentary rules do change. Figure 1 provides a more detailed picture by plotting the total number of words in each country's rules over time.

The figure shows a steady increase in text length for Austria and Germany. In Switzerland, we also see a clear increase over time even though the total number of words slightly decreased after $2005 .{ }^{15}$ Comparing the three countries, parliamentary business is regulated most densely in Austria, which had the longest rules both at the beginning and the end of the period covered as well as during most of the years in between. Germany comes in second for most of the period even though its rules were a little longer than the Austrian ones from 1965 to 1975 and again during the 1980s. The Swiss rules were the shortest of the three during most of the period, especially from the 1990s to $2002 .{ }^{16}$ The particularly dense regulation in Austria is plausible because the country was long divided between two political camps that suspiciously monitored each other even when governing together in a Grand Coalition. This mutual distrust provided strong incentives to codify parliamentary rules instead of relying on informal conventions, in particular when combined with a combative opposition, as was the case in the 1980s and 1990s.

Figure 2 disaggregates the overall changes according to the content-based categories discussed above and plots the number of words relating to 'plenary decision-making', 'intra-parliamentary units', 'external relations and control', 'changing rules', and the residual category for each country. ${ }^{17}$ 
THE LENGTH OF PARLIAMENTARY STANDING ORDERS IN AUSTRIA, GERMANY, AND SWITZERLAND OVER TIME (IN WORDS)

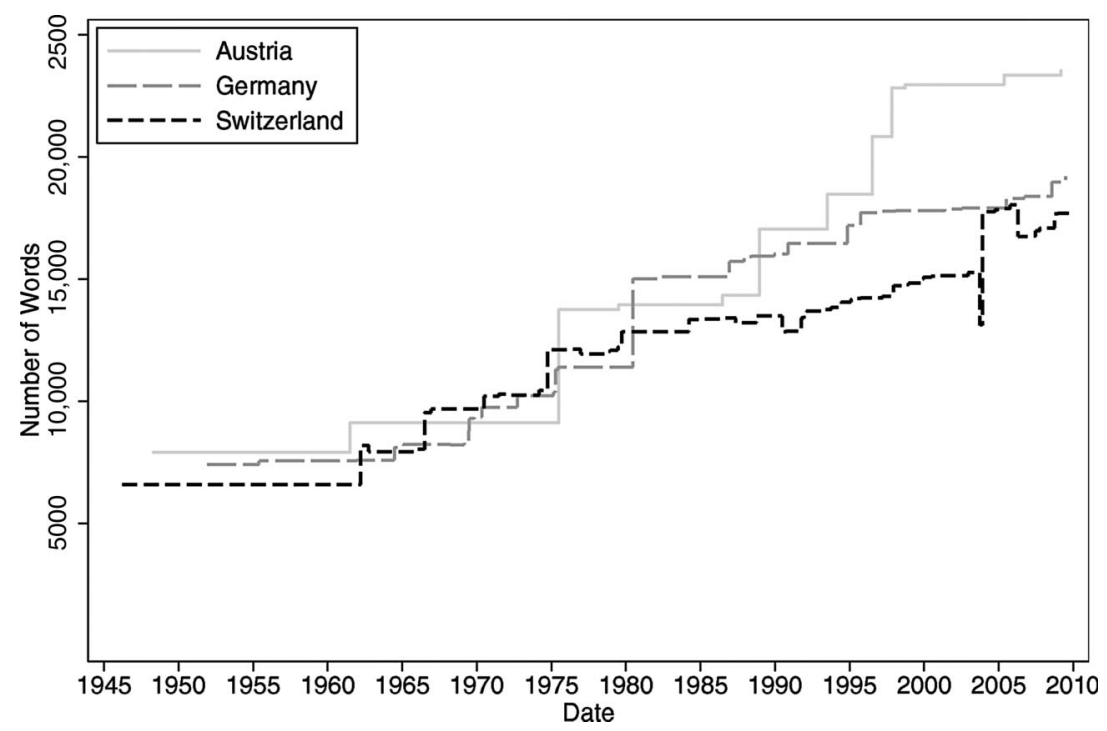

Table 1 provides a numerical measure of the relative increase in text length for each category by calculating the ratio of the length of the most recent compared to the first version after 1945.

The data reveal several patterns in line with our expectations on differences between the content categories. First, as expected, rules concerning the change and interpretation of the standing orders are rather stable over time. Similarly, the increase in the residual 'other' category is below the increase in the total text. ${ }^{18}$ Third, we see the expected strong increase in rules concerning internal units within parliament in all countries. This pattern conforms to our expectation that increased workload and complexity should bring about organisational reactions in parliament.

Two other findings, however, run counter to our expectations. First, the size of the category 'external relations and control' more than quadruples in Austria, while increasing less than average in the other two countries. On average, the share of this category on the total number of words is highest in Austria followed by Switzerland and Germany. These numbers refute our expectation that Switzerland as a non-parliamentary system should put more weight on control. Instead, the high level of distrust among parliamentary actors in Austria manifests itself in extensive and growing rules on control and relations to external bodies. Second, the regulation of plenary decision-making has clearly increased in all three countries. This 
FIGURE 2

THE LENGTH OF PARLIAMENTARY STANDING ORDERS OVER TIME BY CONTENT (IN WORDS)
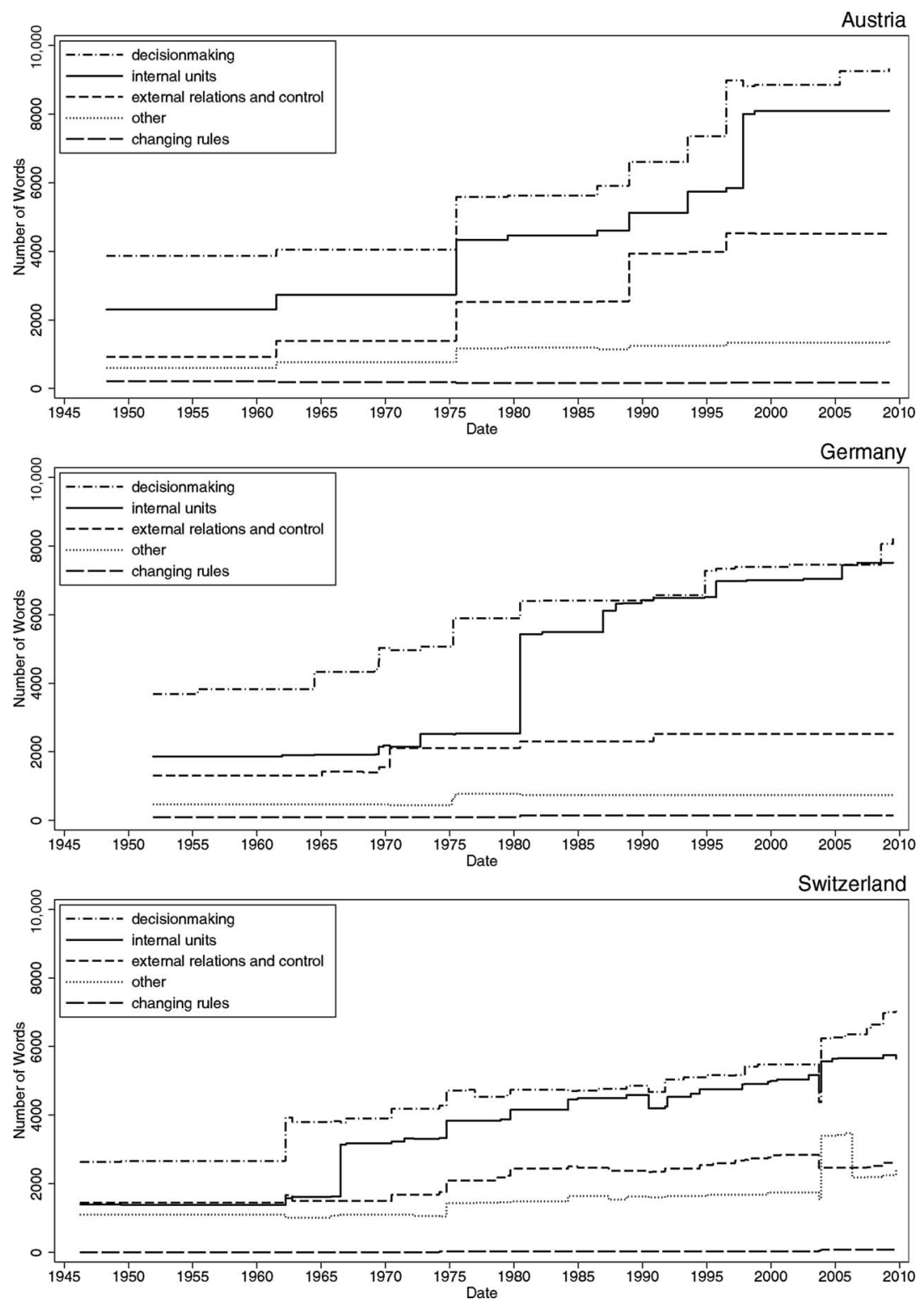

finding is somewhat surprising because many aspects covered by this category have always been integral parts of parliamentary business. leading us to expect more stability in this category. ${ }^{19}$ 
TABLE 1

THE RELATIVE INCREASE IN THE LENGTH OF PARLIAMENTARY STANDING ORDERS OVER TIME BY CONTENT

\begin{tabular}{lccc}
\hline & Austria & Germany & Switzerland \\
\hline Plenary decision making & 2.41 & 2.23 & 2.66 \\
Intra parliamentary units & 3.52 & 4.03 & 4.10 \\
External relations and control & 4.89 & 1.93 & 1.81 \\
Changing rules & 0.86 & 1.51 & $\mathrm{a}$ \\
Other & 2.34 & 1.74 & 2.05 \\
Total & 2.98 & 2.59 & 2.69 \\
\hline
\end{tabular}

Notes: The cells contain the ratio of the number of words relating to this category in the last and the first version of the country's standing order.

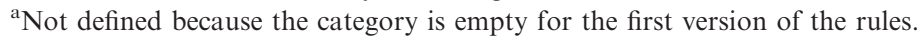

The previous analysis relied on net changes in length and thus only provided a lower limit for the actual amount of change. The real change can be larger if reforms include both additions and deletions to the text and/or the replacement of words by others. Thus, we use an additional measure for gross changes defined as the sum of the numbers of added, deleted, and replaced words for each reform. Figure 3 presents the data on net and gross changes for 12 Austrian, 36 German, and 60 Swiss reforms. ${ }^{20}$ However, we do not calculate gross change for several reforms in which the ordering of paragraphs was altered completely in addition to massive changes in the rules. Under these circumstances, it is almost impossible to systematically identify all parts of the text that remained the same. For this reason, we do not provide gross change measures for the 1975 reform in Austria, the 1980 reform in Germany and the Swiss reforms in March 1962, October 1974, June 1990, October 2003, and December 2003.

Figure 3 shows that the two indicators frequently deviate from each other. This is particularly visible in the few instances where the net length of the Swiss rules decreased while the gross measure of change can only take on positive values. Furthermore, several cases, in which both measures are positive, show substantial variation between net and gross changes. In 32 cases (five in Austria, 13 in Germany, and 14 in Switzerland), our gross change measure is more than twice as high as the absolute value of the net change, in nine cases (four in Germany and five in Switzerland) the ratio is even larger than five. ${ }^{21}$ Substantively, this divergence indicates that a rewriting of parliamentary rules often involves both additions and deletions in the text. Methodologically, it implies that focusing solely on net changes involves the risk of missing relevant changes and drawing a biased picture of the overall extent of reforms. This is certainly a problem for descriptive analysis. The size of the problem for causal analysis depends on the correlation between the two indicators. For Austria, the correlation is extremely high $(r=0.96 ; p<0.001 ; N=11)$ so that analyses using either indicator as dependent variable will probably come to similar results. For 
FIGURE 3

NET AND GROSS CHANGE IN THE LENGTH OF PARLIAMENTARY

STANDING ORDERS

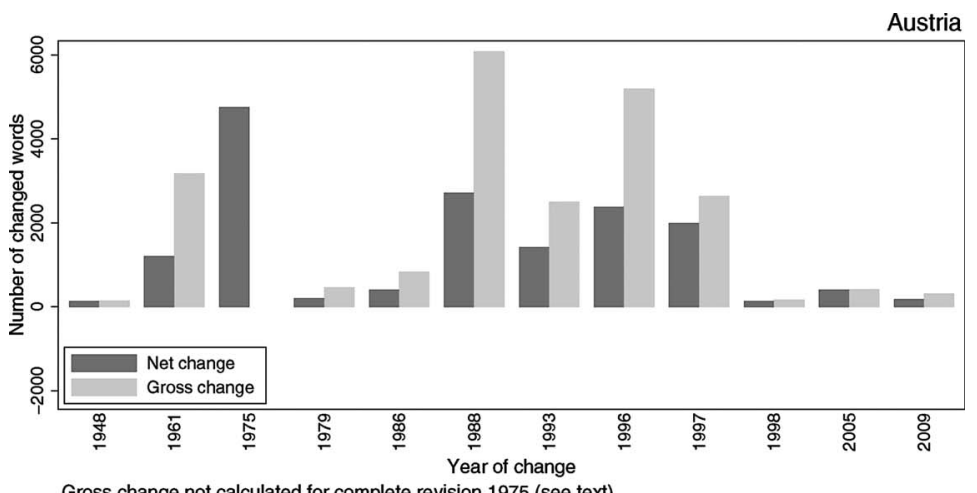

Gross change not calculated for complete revision 1975 (see text)

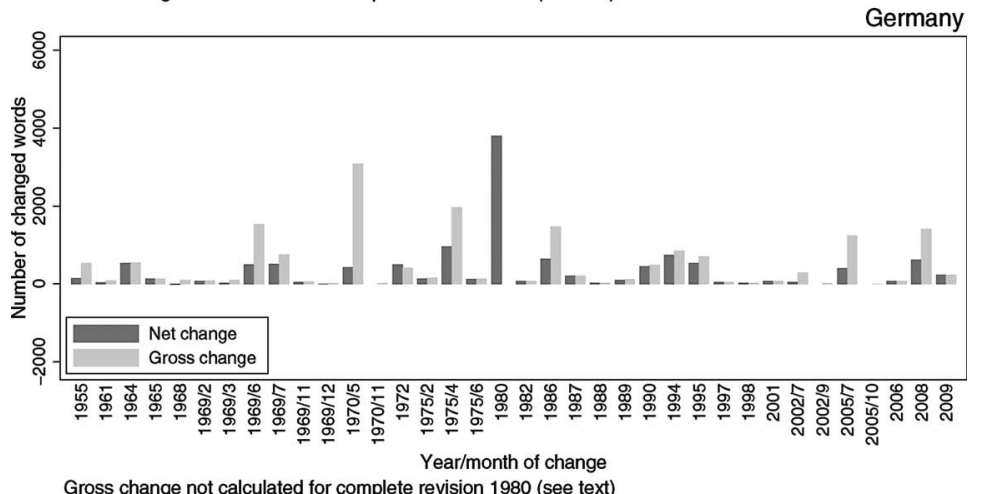

Gross change not calculated for complete revision 1980 (see text)

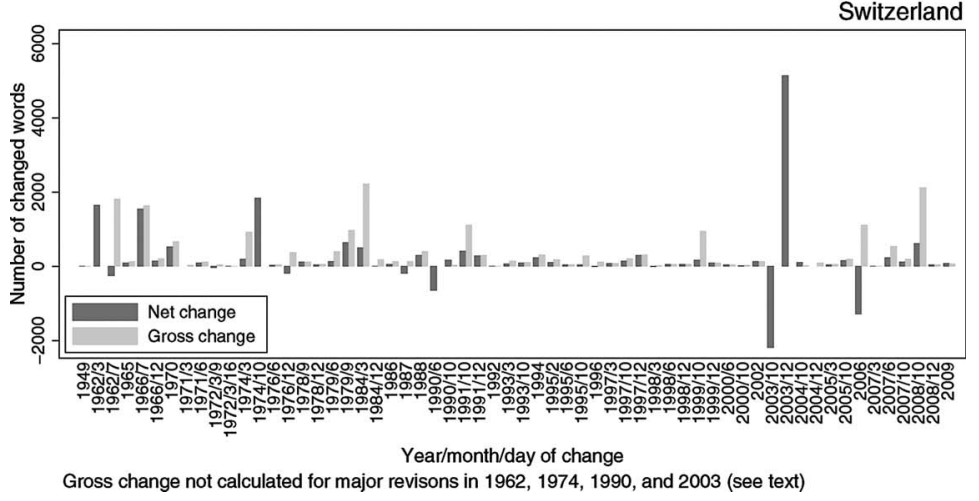

Germany, the correlation is lower $(r=0.75, p<0.001 ; N=35)$ opening up the potential for different results in causal analysis as well. For Switzerland, the correlation is very low $(r=0.33 ; p<0.05 ; N=55)$ for the original data 
mainly due to the cases with negative net change values. When we use the absolute values of both measures, the correlation is only slightly lower than in Germany $(r=0.70 ; p<0.001 ; N=55)$. Overall, these findings indicate that it is often necessary to go through the far more time-consuming process of measuring gross changes.

\section{Rule Changes in Response to Trends in the External Environment}

According to the theoretical model sketched above, long-term trends in the external environment calling for adaptation on the side of parliaments are one reason for rule changes. Such external developments should usually lead to efficient reforms that help all parliamentary actors deal with new or changed demands and maintain the reputation of parliament as a collective body. In this section, we identify three such developments, derive expectations about their effects on rule changes, and confront our expectations with data.

First, the process of European integration has put strain on national parliaments and led to institutional adaptations such as establishing specialised EU committees and designing special procedures for dealing with EU decisions and for influencing the position taken by the government in EU negotiations (Auel and Benz 2005; Bergman 1997). This general trend, however, should have materialised in different degrees and at different times in our three countries. ${ }^{22}$ Germany as a founding member of the EU should have been the first to implement EU-specific parliamentary procedures whereas we expect to see such procedures in the Austrian rules only shortly before the country's accession to the EU in 1995. Furthermore, we expect large changes in parliamentary rules subsequent to major institutional reforms on the European level, especially the increased powers transferred to the EU under the Maastricht Treaty in 1992 and the extended role ascribed to national parliaments in the (never ratified) Constitutional Treaty in 2004 and the Treaty of Lisbon in 2007. No specific rules tied to the EU should exist in Switzerland that is not a EU member state.

Second, the late 1960s and 1970s witnessed intense debates about democratic reform. Starting from the student protests, new social movements denounced the perceived seclusion of the political system and demanded additional institutional means for citizen participation. At least some of these demands were taken up by parliamentary reforms, for example implementing new rules on the publicity of proceedings and new forms of topical debates. A second phase of such reform demands is associated with the end of the Cold War. After the perceived victory of the Western democratic system over its communist rival, new requests surfaced to further democratise existing democracies. Given these external trends, we expect to see rule changes referring to democratic reforms in all three countries, especially in the late 1960s/early 1970s and again in the 1990s.

Third, an established literature on institutionalisation points to increasing demands for specialisation and professionalisation due to the increased 
workload and complexity faced by parliamentary actors (Polsby 1968; Loewenberg and Patterson 1979; Copeland and Patterson 1994). Strengthening parliamentary committees is often regarded as the most promising organisational strategy to address the need for specialisation and division of labour in parliaments (Krehbiel 1991). Thus, we expect to see an increase in the length of rules regulating committees. However, this effect should not be uniform across countries because especially the German Bundestag featured a strong committee system from 1949 onwards. By contrast, the Swiss parliament started out with few rules referring to committees leading us to expect more fundamental changes in response to external pressures. Similarly - as a heritage of the Habsburg Empire - the Austrian rules of procedure had left much of the committee rights and details of proceedings unregulated at the beginning of our period of observation (see Auracher-Jäger 1997; Fischer 1975). Thus, we expect greater increases in rules relating to committees in Switzerland and Austria compared to Germany.

To test these expectations, we have to specify which rules should be affected by these three trends in the external environment. This is fairly simple for European integration, where we use all rules on procedures related to EU business and on specialised EU committees. To capture responses to democratic reform demands, we use all rules on direct democracy, topical debates, parliamentary questions, petitions, committees of enquiry, and parliamentary enquêtes (finding commissions) because these instruments all provide for increased transparency of the political process. Finally, we focus on rules related to parliamentary committees (other than EU committees and committees of inquiry and enquêtes which are included in the measures of European integration and democratic reform, respectively) to measure changes in response to increased workload and complexity because committees are usually considered the main vehicle for increasing organisational capacities. Figure 4 shows the development of the number of words in these three categories of rules over time in our three countries. As we report the total number of words, the changes visible in the graphs are net changes.

The empirical data are largely in line with our expectations. As predicted, Germany was the first country to implement parliamentary rules referring to the EU in 1980. Austria followed in the summer 1993, i.e. one and a half years before joining the EU. In both countries, the amount of regulation increased massively in 1994 and 1996, respectively, in reaction to the increased powers of the EU under the Maastricht Treaty. A second dramatic increase is observed in 2008 and 2005, respectively, linked to the institutional reforms of the (failed) Constitutional Treaty and the subsequent Treaty of Lisbon. Thus, the timing of these rule changes clearly corresponds to major steps in the European integration process as well as to the country-specific date of accession. Furthermore, the level of regulation is quite similar in both countries, 
FIGURE 4

THE EXPANSION OF PARLIAMENTARY STANDING ORDERS WITH REGARD TO THREE TRENDS IN THE EXTERNAL ENVIRONMENT

(TOTAL NUMBER OF WORDS)
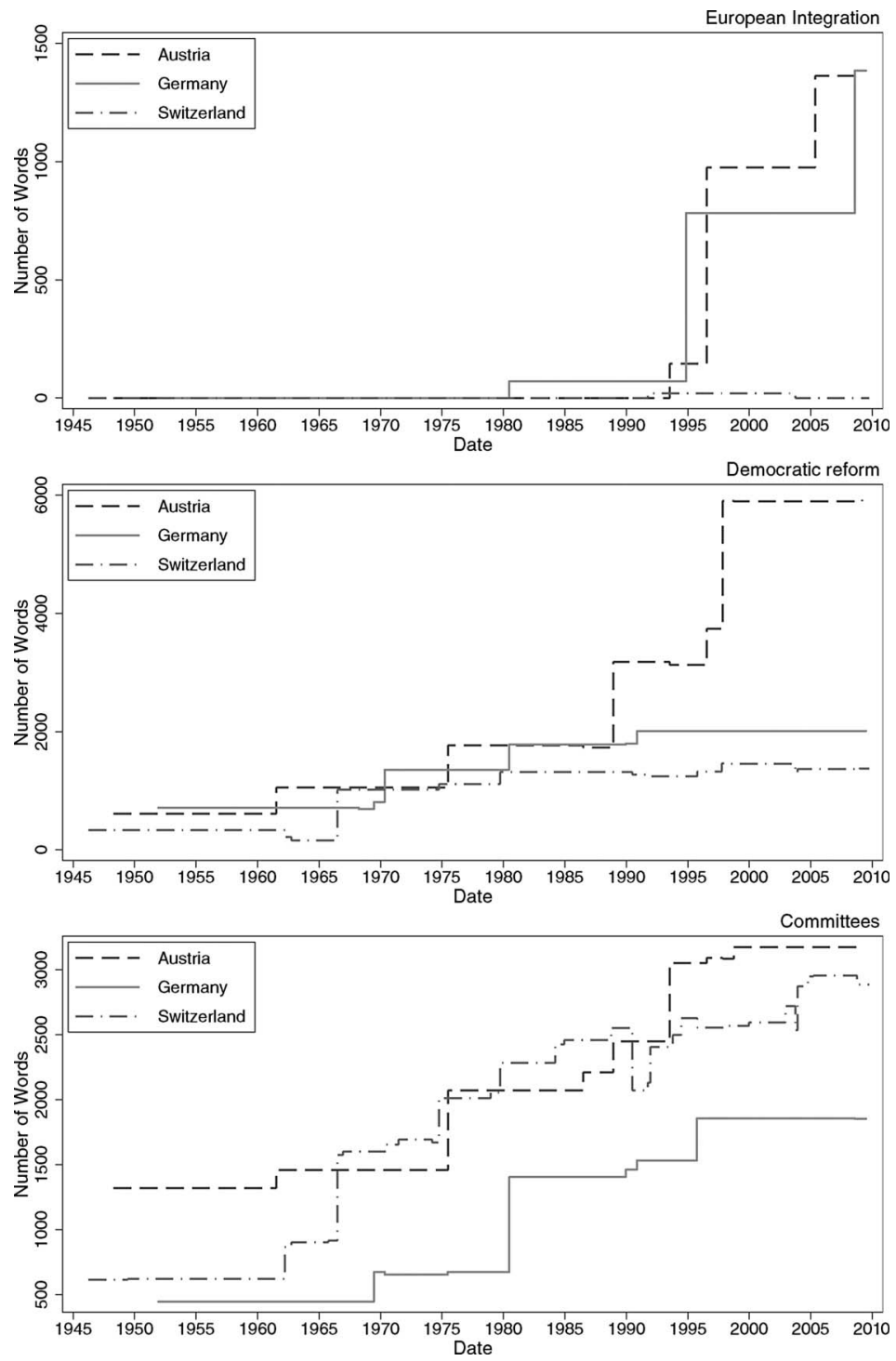

supporting the argument that parliaments react similarly to long-term changes in external demands. As expected, Switzerland has hardly any rules related to the EU. In 1991, a permanent subcommittee of the committee on foreign affairs was established to deal with European 
issues. However, this subcommittee is no longer mentioned in the rules after the 2002 reform.

Second, rule changes relating to demands for democratic reform are observed in all three countries roughly during the times expected. In Austria, major expansions are observed in 1975 (dealing particularly with parliamentary questions, committees of inquiry, topical debates, and direct democracy), 1988 (relating to petitions and topical debates), and 1997 (expanding rules on committees of inquiry); at least the first and the last of these dates fall clearly within the time periods identified as times of intense democratic reform debates. In Germany, the largest increase is observed in 1970 (dealing mainly with parliamentary questions); a smaller one comes somewhat later than expected in the comprehensive rewriting of rules in 1980 (introducing topical debates). ${ }^{23}$ In Switzerland, finally, we see a large increase in 1966 due to the introduction of committees of inquiry followed by relative stability. Overall, Germany and Austria show very similar patterns of expanding rules related to democratic reform demands, especially if we include the special law on committees of inquiry in the German Bundestag (see note 23). The Swiss rules, on the other hand, contain fewer rules related to democratic reforms; note however that direct democracy as the most important element of direct citizen influence in Switzerland is regulated by legal sources other than the standing orders and thus does not enter our analysis.

Third, we observe the expected increase in regulation concerning parliamentary committees. Contrary to our expectations, the trends for the three countries are very similar. Furthermore, changes occur more continuously than in the other graphs. Thus, reforms of the committee system seem to be more gradual, possibly as a reaction to continuous changes in the demands confronted by committees. Finally, the countryspecific differences in the level of regulation are interesting. Despite the strong position of Bundestag committees documented in the comparative literature, German rules spend fewer words on committees than the Austrian and Swiss ones. A portion of this difference is due to the fact that the Austrian and particularly Swiss rules contain extensive regulation on specific committees (in the Swiss case especially the supervisory committees) whereas most German rules apply to all committees alike. If mentions of specific committees are excluded, the German and Swiss rules contain approximately equal number of words on committees. The Austrian rules, however, still contain more regulation on committees even when controlling for the greater overall length of these rules.

The empirical analysis of changes in rules on parliamentary involvement in the European integration process, rules providing transparency and citizen participation, and rules that affect the capacity of parliament to master increases in workload and policy complexity served two main purposes: First, it demonstrated the usefulness of our second measurement approach that relies on the hand-coding of parliamentary rules. Second, it 
allowed a first test of one part of our theoretical framework, i.e. reforms as responses to external developments that disturb equilibrium institutions. We singled out three external trends that ought to be of general interest and allow relatively specific expectations about what rules should be changed. We found these expectations borne out in our three countries. This, of course, does not rule out the possibility that partisan considerations have informed the choice of the specific responses to the external challenges and that actors have benefited differently from these reforms (Cox 1987). Nor does this article provide an empirical test of theoretical arguments about how changes in the actor constellation disturb equilibrium institutions and should lead to redistributive reforms. We leave an empirical analysis of these arguments to future work. We think, however, that the evidence provided on efficient changes makes a strong case for the plausibility of our theoretical reasoning and our novel measurement approach and encourages further work along these lines.

\section{Conclusion}

Despite increased scholarly attention to questions of institutional change our knowledge of reforms in parliamentary rules outside the United States is very limited. This article took several steps towards filling this gap: Theoretically, we sketched a rational choice institutionalist model for explaining rule changes as the outcome of rational actors' choices based on their substantive and, derived from those, institutional preferences. We conceptualised institutions as equilibria in an underlying game on how to conduct business. Based on this perspective, we predicted institutional change in situations where this underlying equilibrium is disturbed and a majority of actors expects higher net benefits from a distinct alternative to the institutional status quo. The article identified both factors that can disturb equilibrium institutions (changes in the actor constellation as well as shocks and long-term trends in the external environment) and factors that stabilise existing institutional arrangements (second-order institutions, political and electoral costs of reforms, and uncertainty about future payoffs under different rules). While we did not specify the theoretical model fully in this article, we did spell out expectations about the effects of three long-term trends in the external environment on rule changes.

Methodologically, we suggested two approaches to measure rule changes: changes in specific institutional variables identified as relevant by previous theoretical and empirical research, and quantitative analysis of all changes to the text corpus which can be divided up based on the content of each rule. Combining these approaches allows us to map rule changes in their entire breadth while also providing sufficient analytic depth by identifying expected effects of changes in specific variables. We demonstrated the usefulness of our newly developed quantitative measure and the contentbased coding scheme for parliamentary rules by applying it to all rule 
changes in the lower parliamentary chambers of Austria, Germany, and Switzerland after 1945.

The empirical analysis revealed frequent and massive changes in parliamentary rules with regard to different aspects of parliamentary activity. It clearly demonstrated that these rules cannot be assumed to be exogenous to political competition and stable over time. Second, we detected systematic differences between countries and content areas that are mostly in line with our theoretical expectations. Finally, we demonstrated that three long-term trends - European integration, demands for democratic reform, and increasing workload and complexity - go hand in hand with changes in related parliamentary rules. While this temporal coincidence should not be taken as proof of a causal relationship because we did not control for alternative explanations, it does provide initial empirical support for key claims of the theoretical model.

Despite its theoretical, methodological, and empirical merits, this article is only a first step in a systematic analysis of parliamentary rules changes in European democracies. In closing, let us thus outline the road to be taken in future research. On the theoretical level, we will more thoroughly specify the model only sketched in this article and derive hypotheses on factors that make change in general, as well as redistributive and efficient changes in particular, more or less likely. Empirically, we will broaden our sample to include all Western European democracies. This research will provide a systematic account of the degree of stability and change in parliamentary rules using the two measures of change discussed above and further our understanding of its causes by systematically testing the theoretically derived hypotheses, both with regard to efficient changes on which we provided some evidence above and to redistributive reforms we leave to future work.

\section{Acknowledgements}

An earlier version of the article was presented at the Annual Meeting of the Section Comparative Politics of the Deutsche Vereinigung für Politikwissenschaft (DVPW) in Duisburg, 20-22 September 2010. We gratefully acknowledge helpful comments and suggestions by Michael Stoiber, Philipp Harfst, and Julia Keh, and excellent research assistance by Evelyn Pauls, Fabian Siegel, and Franziska Steidle-Sailer. We also thank Michael Becher who worked with us earlier in the project. Our research was or is supported by the Deutsche Forschungsgemeinschaft (Grant SI 1470/2-1), the Mannheim Centre for European Social Research (MZES) at the University of Mannheim, and the Zukunftskolleg at the University of Konstanz.

\section{Notes}

1. We confine our argument to formal rules for both theoretical and practical reasons. Theoretically, the effects of informal rules like conventions on appropriate behaviour rest 
on shakier ground because they lack formal enforcement mechanisms. Even though conventions can at times be enforced by informal sanctions, they should not have the same continuous constraining effect on actors as enforceable formal rules. Practically, it is almost impossible to identify all relevant conventions that were in force in a large set of parliaments over an extended period of time as even country experts often have problems specifying when a behavioural pattern solidified into a universally accepted informal rule. By focusing on formal rules we certainly miss some conventions that influence actors' behaviour. However, this limitation is mitigated by the fact that informal rules are often codified at a later point in time, especially if their content was contested. Thus, parliamentary actors obviously do differentiate between formal and informal rules and invest resources into formalising only some conventions, most likely the ones they consider worth carrying the costs that come with formalisation.

2. Additional parliamentary rules are sometimes contained in specific laws, as for example the law on parliamentary committees of inquiry in Germany. Including all parliamentary rules in such laws is impossible due to the large number of potentially relevant sources. However, it is plausible to assume that the overwhelming part of parliamentary rules including the most important ones is contained in either the constitution or the standing orders.

3. Similarly, rules themselves can be characterised as efficient or redistributive depending on whether they are in the interest of all parliamentary actors or only a subset of them.

4. If the current majority fears to lose in upcoming elections, it may have incentives to strengthen the position of the opposition in order to profit from these very rights in the future.

5. Of course, such rules can be overthrown by extra legal means in a revolutionary move. We do not discuss such instances as they are clearly beyond the scope of democratic institutional design.

6. To some extent, this conclusion depends on additional assumptions regarding actors' attitudes towards risk. Our conclusions hold for risk neutral and risk averse actors but may be different under the assumption of risk acceptance. However, risk acceptant behaviour, i.e. an inclination to gamble, is unlikely in the parliamentary context where stakes tend to be high.

7. The comparison was performed using DiffDoc (http://www.softinterface.com/index.htm, accessed 18 April 2011).

8. In future work, we will also use the alternative measurement approach based on specific institutional variables.

9. A subparagraph is any syntactic unit under a legal paragraph (§) or article that is marked off by an own numbering, e.g. 'a' or '(1)'. Such subparagraphs can still consist of more than one sentence. We treat the subparagraph as the smallest unit of analysis and assign it to one category as a whole.

10. As these are not rigorously derived from a theoretical model, we use the term 'expectations' instead of 'hypotheses'.

11. From 1949 to 1951, the Bundestag used a slightly revised version of the 1922 rules from the Weimar Republic while drawing up new rules that were passed in December 1951.

12. These miscellaneous rules often refer to country specific factors (e.g. language issues in Switzerland) or to matters of parliamentary administration that should be quite stable over time.

13. However, the largest reform in 1975 was passed under a one party SPO cabinet with the support of the opposition. This theoretically surprising finding is quite understandable in light of the competitive context after 1945. The Grand Coalition governments of the immediate post war period commanding more than 90 per cent of the parliamentary seats had not been concerned with strengthening minority rights. When the series of Grand Coalition cabinets gave way to the single party majority cabinet of the OVP in 1966, the then opposition SPO raised the issue of strengthening minority rights. Consistent with a redistributive logic, the OVP rejected the demand. When the SPO replaced the OVP in government in 1970 , installing a minority cabinet, the situation suggested that it was 
politically opportune for the SPO to uphold its demand. It nevertheless took several years to conclude inter party negotiations, and the final decision was made shortly before the 1975 elections. As Fischer (1975: 309) put it, it was enacted in a situation where neither the government nor the opposition could be certain who would be the main beneficiary of the more opposition friendly rules. All other larger reforms comprising net changes of more than 1,000 words were passed under Grand Coalitions.

14. The total number of words increased from 7,908 to 23,540 in Austria, from 7,417 to 19,201 in Germany, and from 6,592 to 17,757 in Switzerland. Headings and numbers of paragraphs are not included in the word counts.

In addition, the constitutions of the three countries contain rules on parliament. These rules are changed over time as well, albeit less frequently and less extensively. We currently have measures on the length of constitutional rules referring to parliament for three points in time spaced about equally over the period of investigation. In Austria, the number of words relating to parliament increased from 2,562 in 1948 via 2,843 in 1980 to 5,071 in 2010. In Germany, the respective numbers are 1,855 (1949), 2,746 (1980), and 2,980 (2010). The Swiss constitution contains by far the fewest rules on parliament, amounting to a total number of 385 words in 1946, 391 words in 1980 and 865 words in 2010. These numbers show that the largest part of parliamentary rules is indeed contained in the parliamentary standing orders analysed in this article.

15. The length of the Swiss rules temporarily dropped in October 2002 when the Geschäftsreglement was cut by more than 30 per cent. However, this cut was part of the larger reform that replaced the old Geschäftsverkehrsgesetz with the new Parlamentsgesetz two months later. At the end of the reform, the total number of words had grown considerably due to a massive increase in the length of the Parlamentsgesetz.

16. The same ordering of countries is observed in constitutional rules on parliament (see note 14).

17. As these five categories are mutually exclusive and jointly exhaustive, an addition of the five lines would recreate the total number of words displayed in Figure 1 for each country.

18. A larger increase is observed for the 2002 reform in Switzerland. This increase is mainly due to extensive final provisions on the coming into force of new and expiry of old rules.

19. As this category is rather heterogeneous, we also calculated stability only for rules that refer to ordinary lawmaking (initiation of bills; debate, amendment, and voting on bills; referral of bills to committees). The resulting ratios for the length of the last compared to the first version are lower for Austria (2.25) and especially Germany (1.49) but higher for Switzerland (3.05) when compared with the ratios for the broader category in Table 1. Thus, the rules on lawmaking in a narrow sense also grew considerably since 1945 .

20. We cannot calculate the number of changed words for the first observation in Germany and Switzerland because of missing data on the rules in effect before 1951 (in Germany) and 1946 (in Switzerland), respectively.

21. We use the absolute value of the net change measure in order to make the cases of net decrease in Switzerland comparable.

22. These differences highlight another advantage of our country selection. Among Western European democracies, Switzerland is one of only three non EU countries (besides Norway and Iceland) while Germany and Austria have very distinct trajectories of EU membership.

23. Since 2001, a special law regulates procedures of committees of inquiry in the Bundestag (Untersuchungsausschussgesetz). In 2010, this law comprised 3,519 words. If these rules are included in the count, the total number of words regarding democratic reform in Germany is much closer to the level observed in Austria from 2001 onwards.

\section{References}

Auel, Kathrin, and Arthur Benz (2005). 'The Politics of Adaptation: The Europeanisation of National Parliamentary Systems', Journal of Legislative Studies, 11:3, 37297. 
Auracher Jager, Barbara (1997). Die Mechanismen im Nationalrat. Ihre Entwicklung in Geschäftsordnung und $B V G$. Wien: Verlag Osterreich.

Benoit, Kenneth (2004). 'Models of Electoral System Change', Electoral Studies, 23:3, 363 89.

Benoit, Kenneth (2007). 'Electoral Laws as Political Consequences. Explaining the Origins and Change of Electoral Institutions', Annual Review of Political Science, 10, 36390.

Benz, Arthur, and Nathalie Behnke, eds. (2009). Federalism and Constitutional Change. Special issue of Publius, 39:2.

Bergman, Torbjorn (1997). 'National Parliaments and EU Affairs Committees: Notes on Empirical Variation and Competing Explanations', Journal of European Public Policy, 4:3, 37387.

Bergman, Torbjorn, Wolfgang C. Muller, Kaare Strøm, and Magnus Blomgren (2003). 'Democratic Delegation and Accountability: Cross national Patterns', in Kaare Strøm, Wolfgang C. Muller, and Torbjorn Bergman (eds.), Delegation and Accountability in Parliamentary Democracies. Oxford: Oxford University Press, 109220.

Binder, Sarah A. (1996). 'The Partisan Basis of Procedural Choice: Allocating Parliamentary Rights in the House, 1789 1990', American Political Science Review, 90:1, 820.

Binder, Sarah A. (1997). Minority Rights, Majority Rule. Partisanship and the Development of Congress. Cambridge: Cambridge University Press.

Binder, Sarah A. (2006). 'Parties and Institutional Choice Revisited', Legislative Studies Quarterly, 31:4, 51332.

Calvert, Randall L. (1995). 'Rational Actors, Equilibrium, and Social Institutions', in Jack Knight and Itai Sened (eds.), Explaining Social Institutions. Ann Arbor, MI: University of Michigan Press, 5793.

Carroll, Royce, Gary W. Cox, and Mónica Pachón (2006). 'How Parties Create Electoral Democracy, Chapter 2', Legislative Studies Quarterly, 31:2, 15374.

Congleton, Roger D. (2003). Improving Democracy Through Institutional Reform. Some Swedish Lessons. Boston: Kluwer Academic Publishers.

Copeland, Gary W., and Samuel C. Patterson, eds. (1994). Parliaments in the Modern World. Changing Institutions. Ann Arbor, MI: University of Michigan Press.

Cox, Gary W. (1987). The Efficient Secret. The Cabinet and the Development of Political Parties in Victorian England. Cambridge: Cambridge University Press.

Cox, Gary W. (2000). 'On the Effects of Legislative Rules', Legislative Studies Quarterly, 25:2, 16992.

Diermeier, Daniel, and Keith Krehbiel (2003). 'Institutionalism as a Methodology', Journal of Theoretical Politics, 15:2, 12344.

Dion, Douglas (1997). Turning the Legislative Thumbscrew. Minority Rights and Procedural Change in Legislative Politics. Ann Arbor, MI: University of Michigan Press.

Doring, Herbert, ed. (1995a). Parliaments and Majority Rule in Western Europe. Frankfurt am Main: Campus.

Doring, Herbert (1995b). 'Time as a Scarce Resource: Government Control of the Agenda', in Herbert Doring (ed.), Parliaments and Majority Rule in Western Europe. Frankfurt am Main: Campus, 22346.

Doring, Herbert, and Mark Hallerberg, eds. (2004). Patterns of Parliamentary Behavior. Passage of Legislation across Western Europe. Burlington, VT: Ashgate.

Elkins, Zachary, Tom Ginsburg, and James Melton (2010). The Endurance of National Constitutions. Cambridge: Cambridge University Press.

Elster, Jon, Claus Offe, Ulrich K. Preuss, and Frank Boenker (1998). Institutional Design in Post Communist Societies. Rebuilding the Ship at Sea. Cambridge: Cambridge University Press.

Filipe, António (2009). 'The 2007 Reform of the Portuguese Parliament. What Has Really Changed?', Journal of Legislative Studies, 15:1, 19.

Fischer, Heinz (1975). 'Die Reform der Geschaftsordnung des osterreichischen Nationalrates nach dem Ende der großen Koalition', Zeitschrift für Parlamentsfragen, 6:3, 297309. 
Flinders, Matthew (2007). 'Analysing Reform. The House of Commons, 2001 5', Political Studies, 55:1, 174200.

Foundethakis, Penelope (2003). 'The Hellenic Parliament: The New Rules of the Game', Journal of Legislative Studies, 9:2, 85106.

Franklin, Bob (1989). 'Televising Legislatures. The British and American Experience', Parliamentary Affairs, 42:4, 485502.

Greif, Avner, and David D. Laitin (2004). 'A Theory of Endogenous Institutional Change', American Political Science Review, 98:4, 63352.

Heidar, Knut, and Ruud Koole, eds. (2000). Parliamentary Party Groups in European Democracies: Political Parties Behind Closed Doors. London: Routledge.

Heller, William B. (2001). 'Making Policy Stick. Why the Government Gets What It Wants in Multiparty Parliaments', American Journal of Political Science, 45:4, 78098.

Huber, John D. (1996). 'The Vote of Confidence in Parliamentary Democracies', American Political Science Review, 90:2, 26982.

Héritier, Adrienne (2007). Explaining Institutional Change in Europe. Oxford: Oxford University Press.

Jenny, Marcelo, and Wolfgang C. Muller (1995). 'Presidents of Parliaments. Neutral Chairmen or Assets of the Majority?', in Herbert Doring (ed.), Parliaments and Majority Rule in Western Europe. Frankfurt am Main: Campus, 32664.

Katz, Richard S. (2005). 'Why Are There So Many (or So Few) Electoral Reforms?', in Michael Gallagher and Paul Mitchell (eds.), The Politics of Electoral Systems. Oxford: Oxford University Press, 5776.

Knight, Jack (1992). Institutions and Social Conflict. Cambridge: Cambridge University Press.

Krehbiel, Keith (1991). Information and Legislative Organization. Ann Arbor, MI: University of Michigan Press.

Loewenberg, Gerhard, and Samuel C. Patterson (1979). Comparing Legislatures. Boston, MA: Little, Brown and Company.

Mahoney, James (2000). 'Path Dependence in Historical Sociology', Theory and Society, 29:4, 50748.

Mahoney, James, and Kathleen Thelen, eds. (2010a). Explaining Institutional Change. Ambiguity, Agency, and Power. Cambridge: Cambridge University Press.

Mahoney, James, and Kathleen Thelen (2010b). 'A Theory of Gradual Institutional Change', in James Mahoney and Kathleen Thelen (eds.), Explaining Institutional Change. Ambiguity, Agency, and Power. Cambridge: Cambridge University Press, 137.

Marschall, Stefan (1999). Parlamentsreform. Ziele, Akteure, Prozesse. Opladen: Leske + Budrich.

Marschall, Stefan (2001). 'Das Parlament in der Mediengesellschaft Verschrankungen zwischen parlamentarischer und massenmedialer Arena', Politische Vierteljahresschrift, 42:3, 388413.

Mattson, Ingvar (1995). 'Private Members' Initiatives and Amendments', in Herbert Doring (ed.), Parliaments and Majority Rule in Western Europe. Frankfurt am Main: Campus, 44887.

Mattson, Ingvar, and Kaare Strøm (1995). 'Parliamentary Committees', in Herbert Doring (ed.), Parliaments and Majority Rule in Western Europe. Frankfurt am Main: Campus, 249307.

Mattson, Ingvar, and Kaare Strøm (2004). 'Committee Effects on Legislation', in Herbert Doring and Mark Hallerberg (eds.), Patterns of Parliamentary Behavior. Passage of Legislation Across Western Europe. Burlington, VT: Ashgate, 91111.

Muller, Wolfgang C. (2002). 'Parties and the Institutional Framework', in Kurt Richard Luther and Ferdinand Muller Rommel (eds.), Political Parties in the New Europe. Oxford: Oxford University Press, 25192.

Muller, Wolfgang C., and Kaare Strøm, eds. (1999). Policy, Office, or Votes? How Political Parties in Western Europe Make Hard Decisions. Cambridge: Cambridge University Press.

North, Douglass C. (1990). Institutions, Institutional Change and Economic Performance. Cambridge: Cambridge University Press. 
Norton, Philip (2000). 'Reforming Parliament in the United Kingdom: The Report of the Commission to Strengthen Parliament', Journal of Legislative Studies, 6:3, 114.

Pierson, Paul (2004). Politics in Time. History, Institutions, and Social Analysis. Princeton, NJ: Princeton University Press.

Pierson, Paul, and Theda Skocpol (2002). 'Historical Institutionalism in Contemporary Political Science', in Ira Katznelson and Helen V. Milner (eds.), Political Science. The State of the Discipline. New York: W.W. Norton, 693721.

Polsby, Nelson W. (1968). 'The Institutionalization of the U.S. House of Representatives', American Political Science Review, 62:1, 144168.

Polsby, Nelson W. (2004). How Congress Evolves. Social Bases of Institutional Change. Oxford: Oxford University Press.

Rasch, Bjorn Erik (1995). 'Parliamentary Voting Procedures', in Herbert Doring (ed.), Parliaments and Majority Rule in Western Europe. Frankfurt am Main: Campus, 488527.

Rasch, Bjorn Erik, and George Tsebelis, eds. (2011). The Role of Governments in Legislative Agenda Setting. London: Routledge.

Riker, William H. (1980). 'Implications from the Disequilibrium of Majority Rule for the Study of Institutions', American Political Science Review, 74:2, 43246.

Russell, Meg (2000). Reforming the House of Lords. Lessons from Overseas. Oxford: Oxford University Press.

Russo, Federico, and Matti Wiberg (2010). 'Parliamentary Questioning in 17 European Parliaments: Some Steps towards Comparison', Journal of Legislative Studies, 16:2, 21532.

Saalfeld, Thomas (1995). 'On Dogs and Whips. Recorded Votes', in Herbert Doring (ed.), Parliaments and Majority Rule in Western Europe. Frankfurt am Main: Campus, 52865.

Sartori, Giovanni (1997). Comparative Constitutional Engineering. An Inquiry into Structures, Incentives and Outcomes. 2nd ed. New York: New York University Press.

Schickler, Eric (2000). 'Institutional Change in the House of Representatives, 1867 1998: A Test of Partisan and Ideological Power Balance Models', American Political Science Review, 94:2, 26988.

Schickler, Eric (2001). Disjointed Pluralism. Institutional Innovation and the Development of the U.S. Congress. Princeton, NJ: Princeton University Press.

Schnapp, Kai Uwe, and Philipp Harfst (2005). 'Parlamentarische Informations und Kon trollressourcen in 22 westlichen Demokratien', Zeitschrift für Parlamentsfragen, 36:2, 34870.

Shepsle, Kenneth A. (1986). 'Institutional Equilibrium and Equilibrium Institutions', in Herbert F. Weisberg (ed.), Political Science: The Science of Politics. New York: Agathon Press, 5181.

Shepsle, Kenneth A. (2006a). 'Old Questions and New Answers about Institutions. The Riker Objection Revisited', in Barry Weingast and Donald Wittman (eds.), The Oxford Handbook of Political Economy. Oxford: Oxford University Press, 103149.

Shepsle, Kenneth A. (2006b). 'Rational Choice Institutionalism', in R.A.W. Rhodes, Sarah A. Binder, and Bert A. Rockman (eds.), The Oxford Handbook of Political Institutions. Oxford: Oxford University Press, 2338.

Sieberer, Ulrich (2006). 'Agenda Setting in the German Bundestag. A Weak Government in a Consensus Democracy', German Politics, 15:1, 4972.

Sieberer, Ulrich (2010). Parlamente als Wahlorgane. Parlamentarische Wahlbefugnisse und ihre Nutzung in 25 europäischen Demokratien. Baden Baden: Nomos.

Sieberer, Ulrich (2011). 'The Institutional Power of Western European Parliaments: A Multidimensional Analysis', West European Politics, 34:4, 73154.

Streek, Wolfgang, and Kathleen Thelen, eds. (2005). Beyond Continuity. Institutional Change in Advanced Political Economies. Oxford: Oxford University Press.

Strøm, Kaare (1990). 'A Behavioral Theory of Competitive Political Parties', American Journal of Political Science, 34:2, 56598.

Strøm, Kaare, Wolfgang C. Muller, and Torbjorn Bergman, eds. (2003). Delegation and Accountability in Parliamentary Democracies. Oxford: Oxford University Press.

Swendon, Wilfried, and Maarten Theo Jans (2006). “'Will it Stay or Will it Go?" Federalism and the Sustainability of Belgium', West European Politics, 29:5, 87794. 
Taylor, Andrew J. (2006). 'Size, Power, and Electoral Systems: Exogenous Determinants of Legislative Procedural Choice', Legislative Studies Quarterly, 31:3, 32345.

Thaysen, Uwe (1972). Parlamentsreform in Theorie und Praxis. Zur institutionellen Lernfähigkeit des parlamentarischen Regierungssystems. Opladen: Westdeutscher Verlag.

Thelen, Kathleen (2003). 'How Institutions Evolve. Insights from Comparative Historical Analysis', in James Mahoney and Dietrich Rueschemeyer (eds.), Comparative Historical Analysis in the Social Sciences. Cambridge: Cambridge University Press, 20840.

Tsebelis, George (1990). Nested Games. Rational Choice in Comparative Politics. Berkeley, CA: University of California Press.

Tsebelis, George (2002). Veto Players. How Political Institutions Work. Princeton, NJ: Princeton University Press.

Wawro, Gregory J., and Eric Schickler (2006). Filibuster. Obstruction and Lawmaking in the U.S. Senate. Princeton, NJ: Princeton University Press.

Weingast, Barry R. (2002). 'Rational Choice Institutionalism', in Ira Katznelson and Helen V. Milner (eds.), Political Science. The State of the Discipline. New York: W.W. Norton, 66092. Wiberg, Matti (1995). 'Parliamentary Questioning. Control by Communication?', in Herbert Doring (ed.), Parliaments and Majority Rule in Western Europe. Frankfurt am Main: Campus, 179222. 